\title{
Demography, Diversity and Nativism in Contemporary Africa: Evidence from Uganda
}

\author{
Elliott D. Green \\ Development Studies Institute \\ London School of Economics \\ E.D.Green@lse.ac.uk
}

Paper prepared for presentation at the ASEN Conference on Political

Demography, London School of Economics and Political Science

September 2006

\section{Introduction}

The relationship between population growth, ethnic diversity and conflict in the developing world is little understood but highly relevant to a large number of countries. Countries with high population growth rates and high ethnic diversity like the Republic of Congo, the Democratic Republic of Congo and Uganda are indeed conflict ridden, but it is unclear as to the causal factors behind their various conflicts.

In this paper I examine a case study of local conflict from Uganda with the purpose of teasing out the relationship between these variables. What makes Uganda unusual is its combination of a high population growth rate and a high level of ethnic diversity. As for the former, Uganda's growth rate has continued to climb over the past few years to the point where its projected growth to 2015 is now 3.7\%, second in the world only to East Timor (UNDP 2005; see table 1). Despite worries from the Ugandan Ministry of Health in 1989 that the country's fertility rate was too high and women lacked access to and information about contraception (Republic of Uganda 1989), Museveni's administration did not support family planning until 1994 and did not institute a population policy until 1995 (Blacker et al. 2005: 367-368). The result is that Uganda is now the fastest-growing country in Africa and is set to surpass Russia in population by mid-century.

Table 1: Uganda's Predicted Annual Population Growth Rate (Sources: Various Human Development Reports)

\begin{tabular}{|llll|}
\hline Years & Growth Rate (to 2015) & Worldwide Rank & Projected Population (2015) \\
\hline $1999 / 00$ & $3.1 \%$ & $3^{\text {rd }}$ & $34.5 \mathrm{~m}$ \\
$2001 / 02$ & $3.4 \%$ & $3^{\text {rd }}$ & 38.7 \\
$2003 / 04$ & $3.5 \%$ & $3^{\text {rd }}$ & 39.3 \\
$2005 / 06$ & $3.7 \%$ & $2^{\text {nd }}$ & 41.9 \\
\hline
\end{tabular}

While some demographers and scholars claim that moderate levels of population growth are good for development, others argue that very high population growth rates can have serious negative consequences, not least in fomenting international wars (Tir and Diehl 1998) as well as internal civil conflict (Collier and Hoeffler 2000; Homer-Dixon 1999). Yet the Ugandan population is not only unusual due to its high population growth rate but to its similarly extreme ethnic diversity. According to Fearon (2003), Uganda is the fourth-most ethnically diverse country in 
the world, with the largest ethnic group, the Baganda, only comprising $17 \%$ of the population according to the 2002 census (see table 2). The recent burst of literature on the causes of civil war have suggested that, unlike population growth, ethnic diversity does not have a linear relationship with conflict. Rather, suggest Collier and Hoeffler (1998), De Soysa (2002), Reilly (2000) and others, ethnic diversity and conflict have an inverse-U relationship, whereby both low and high levels of ethnic diversity lead to low levels of conflict. Similarly, Fearon and Laitin (1996) argue that situations of ethnic diversity lead to cooperation between ethnic groups rather than conflict more than $99 \%$ of the time.

\section{Table 2: Ethnic Fragmentation and Population Growth (Sources: Fearon 2003, UNDP 2005)}

\begin{tabular}{|lll|}
\hline Country & Ethnic Fragmentation Index & Growth Rate (2003-2015) \\
\hline Papua New Guinea & 1 & $1.8 \%$ \\
Tanzania & 0.953 & $1.8 \%$ \\
Dem. Republic of Congo & 0.933 & $3.0 \%$ \\
Uganda & $\mathbf{0 . 9 3 0}$ & $\mathbf{3 . 7 \%}$ \\
Cameroon & 0.887 & $1.6 \%$ \\
Togo & 0.883 & $2.5 \%$ \\
South Africa & 0.880 & $0.2 \%$ \\
Republic of Congo & 0.878 & $3.1 \%$ \\
Madagascar & 0.861 & $2.5 \%$ \\
Gabon & 0.857 & $1.5 \%$ \\
\hline
\end{tabular}

These two literature, in other words, predict different trajectories for Uganda. But what happens when the two variables meet? Almost by definition, some ethnic groups will have larger population growth rates than others, thereby leading to tension between groups. One example of this phenomenon are differing growth rates among Hindus and Muslims in India, which has led to often-hysteric statements from Hindu leaders (DeVotta 2002). Yet, as Krebs and Levy (2001: 82) note, 'although the proposition that differential growth in the populations of ethnic communities produces tension and conflict is widely held, it lacks a firm theoretical grounding,' primarily because, as with ethnic diversity alone, it over-predicts conflict. Similarly, both Tir and Diehl (1998) and Urdal (2005) suggest that population growth by itself is not sufficient in explaining militarized conflict.

In other words, the literature would suggest that we would not expect a large amount of interstate or intrastate conflict in Uganda as a result of its high population growth and high ethnic diversity. However, before we jump to conclusions, it is important to note that the above studies of the relationship between demography and conflict exist are largely quantitative in nature. As such they are based on data sets the PRIO/Uppsala Armed Conflict Dataset for Urdal (2005) and Correlates of War for Tir and Diehl (1998) - which measure large-scale military conflict. Both data sets are both very well tabulated and constantly updated, which helps to explain why so many researchers have found them so useful.

\footnotetext{
${ }^{1}$ Fearon (2003)'s Ethnic Fragmentation Index (EFI) is measured on a scale between 0 and 1, whereby the number represents the percentage that two citizens of a given country will come from a different ethnic group. As the EFI only measures ethnic groups which comprise more than $1 \%$ of a country's population, the 'perfectly fractionalized state' of Papua New Guinea tops the list (Fearon 2003: 205).
} 
However, what these data sets do not do is measure local violence in rural areas. Specifically, the point of these data sets is to help scholars explain war, whether interstate or intrastate, rather than local conflict which does not threaten existence of a state. However, if one is to understand the relationship between demography and conflict it is just as important to examine the micro-level of local conflict as it is to discuss the macro-level picture. Yet rural conflict is especially difficult to measure, especially in developing countries where data does not exist or is of dubious quality. Here it would, of course, be very interesting to develop an econometric analysis of the relationship between population growth, ethnic diversity and local-level conflict, but it is daunting to think about the effort that would need to be extended to develop a good cross-national data set of rural conflict. Indeed, what analyses of local-level conflict in developing countries do exist are largely based on already extant data sets collected by local authorities (Alston et al. 2001), and often supplemented by qualitative field work by scholars (Barron et al. 2004).

Of course, the inquisitive scholar cannot wait for the country of his choice to develop a data set of local conflict along the lines of Brazil or Indonesia, but neither would it be prudent for him/her to set out to create a new dataset without a very large research team (and concomitant research grant) and/or an excellent source of local information for all the areas in question. ${ }^{2}$ In lieu of such resources, my focus here will be on the district of Kibaale in western Uganda where the impact of ethnic diversity and population growth has already brought about communal violence. It will be my claim here that the conflict in question was indeed sparked by population growth and resultant internal migration, but has nothing to do with ethnic diversity per se. Rather, I claim that the conflict in Kibaale has much more to do with nativism and the failure of nation-building in post-colonial Uganda. In other words, I claim that ethnic salience, rather than ethnic diversity, is a causal factor along with population growth for the ongoing conflict in Kibaale. In doing so I claim Kibaale may prove something of a warning sign for other parts of Uganda and other developing countries with similar high population growth and little success of nationbuilding.

This paper is structured as follows. First, I give an overview of the conflict in Kibaale. Second, I examine the role of both population growth and ethnicity as possible explanations for the outbreak of violence in the district. Third and finally, I conclude.

\section{A Brief History of Kibaale District}

Kibaale district is situated in west-central Uganda, on the south-eastern tip of Lake Albert (see Figure 1 below). What is today Kibaale district was previously the two counties of Buyaga and Bugangaizi, a core part of the pre-colonial kingdom of Bunyoro. Upon their arrival in the country, however, the British granted the territory to neighbouring kingdom of Buganda as part of their subjugation of Bunyoro in the early 1890s. This loss, along with other territorial transfers at the onset of colonial rule, led to continued resentment in Bunyoro against the British over the life of the Ugandan Protectorate. As Buyaga and Bugangaizi counties were largely populated by Banyoro - unlike the other areas granted to Buganda - their inhabitants also

\footnotetext{
${ }^{2}$ One potential example of such a source is, of course, local media; a well-known example of such a study based on data collected through local media is Varshney (2002), who collected data of communal riots through extensive reading of the Times of India. However, perhaps recognizing the limitations of newspaper reporting, Varshney (2002) explicitly limited himself to urban areas.
} 
continued to oppose Bugandan rule over the course of colonial rule; this resistance was institutionalized in 1921 with the establishment of the Mubende Banyoro Committee (MBC). ${ }^{3}$ Nonetheless, despite repeated protests and petitions from both the Omukamas (kings) of Bunyoro and the native Banyoro of Buyaga and Bugangaizi, the British refused to reverse their earlier decision. ${ }^{4}$

Figure 1: Map of Kibaale District in Uganda

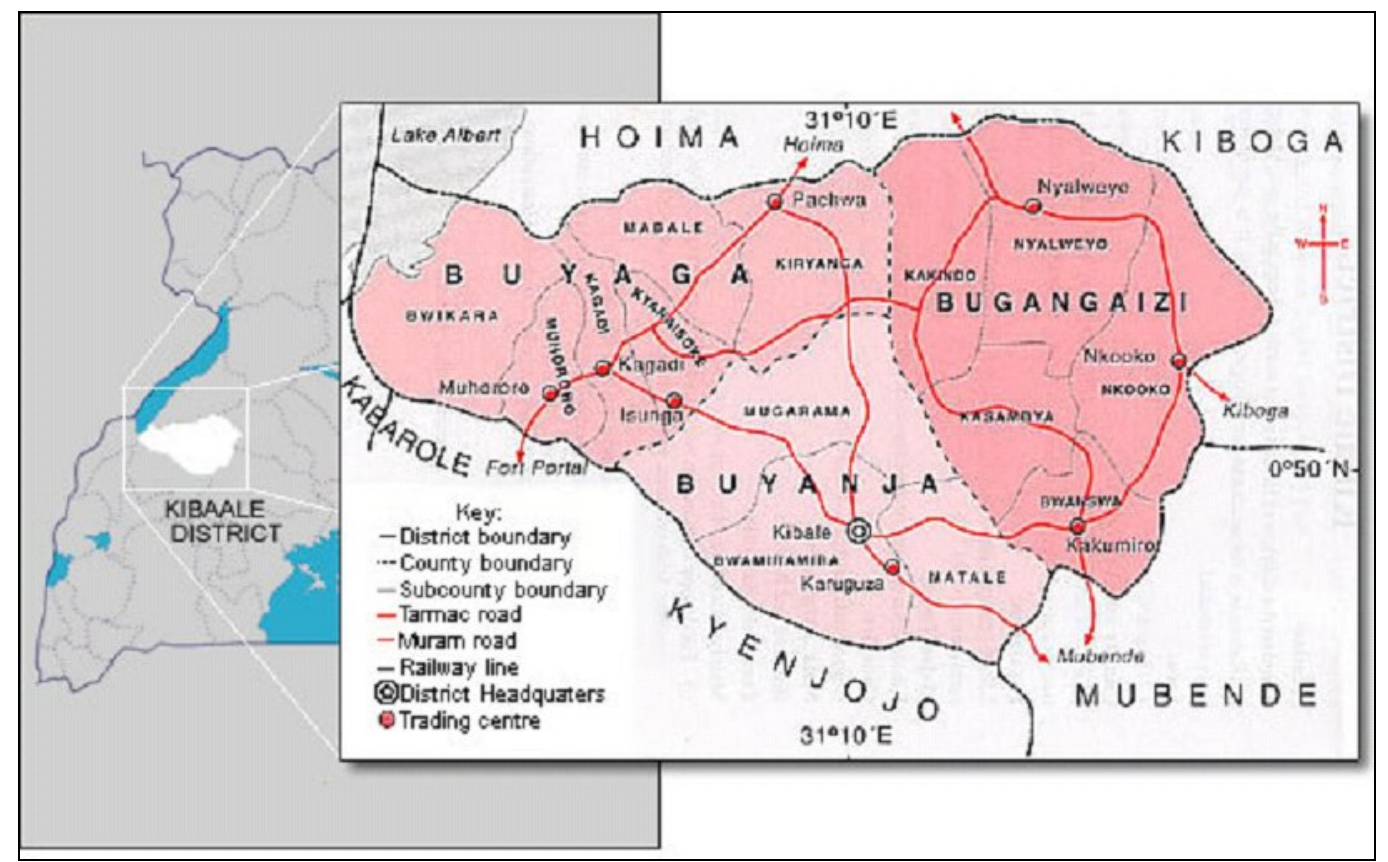

Much of the anger of the Banyoro revolved around the fact that the British had introduced freehold landholding in Uganda in 1900, and had thereby granted Baganda landlords much of the best land in Buyaga and Bugangaizi. ${ }^{5}$ Despite the fact that the Banyoro were eventually granted a referendum in 1964 on whether they wanted to remain part of Buganda or rejoin Bunyoro, the issue of land ownership never arose. Thus, despite an overwhelming vote to secede from Buganda in the referendum, the Baganda landlords continued to own land in the area, although due to the ongoing resentment about Bugandan overrule, they dared not bother come and collect any rent on their property (Interview with District Chairman George Namyaka, Kibaale town, 9/8/05).

While over the next forty years Buyaga and Bugangaizi saw little change in its land holding structure, the area did see a large amount of in-migration from other parts of Uganda, especially of ethnic Bakiga from the region of Kigezi in south-west Uganda from the 1970s onwards. While there was initially little tension between the native Banyoro and immigrant Bakiga, the second influx of Bakiga in the early 1990s began to raise tensions between the two groups. The settlers' political strength first became apparent when they elected Robert Kakooza, a Mukiga, as MP for Buyaga

\footnotetext{
${ }^{3}$ Buyaga and Bugangaizi were part of Mubende district, one of four sub-divisions of colonial Buganda.

${ }^{4}$ This so-called 'lost counties' issue is covered in more detail in Green (2006b).

${ }^{5}$ The Kabaka (King) and his administrators in the Buganda kingdom were allowed to choose the best land as their freehold property, leaving the other $48 \%$ of land in the region to become Crown land (Green 2006a).
} 
county in 1996; Kakooza was, however, replaced by Ignatius Musisira, a Munyoro, in the subsequent 2001 election.

By this time Kibaale district had been formed out of Hoima district in accordance with President Museveni's long-term plan to decentralize power to local Resistance Council (RC) governments while also increasing the number of districts in Uganda. ${ }^{6}$ Indeed, the current conflict began with from the election of Fred Ruremera, a Mukiga, as District Chairman over the incumbent Munyoro Sebastian Ssekitolekko in early 2002. The MBC, which had been resurrected in response to Ruremera's campaign the previous year, launched a campaign of violence that included hate speech on local radio. Violence inevitably broke out after the election, with several Bakiga murdered by Banyoro extremists and many more being threatened with expulsion from the district, leading to the deployment of anti-riot police. President Museveni responded with his first-ever - and so far only - use of clause 202 of the 1995 Constitution of Uganda, which allowed him to take over the rule of a district in exceptional circumstances, thereby negating Ruremera's election. Indeed, rather than reprimand the MBC or other extremists, Museveni replaced Ruremera with George Namyaka, a native Munyoro, in order to calm the situation.

\section{Explaining Conflict in Kibaale}

The ongoing conflict in Kibaale has drawn national attention in Uganda as an unfortunate example of ethnic conflict in a country that was supposed to have healed its ethnic wounds under President Museveni’s 'no party' political system. The MBC has naturally drawn criticism from various pundits as an racist and violent organization, leading one commentator to compare its radio pronouncements as comparable to the hate speech of the Radio de Mille Collines that was partially responsible for the 1994 Rwandan genocide. Many local Banyoro have also cast their anger at the failure of Museveni's government to follow through with its promise, as written explicitly in Uganda's 1998 Land Act, ${ }^{7}$ to transfer land ownership from absentee Baganda landlords to Banyoro tenants.

Both of these factors have undoubtedly played a role in the conflict in Kibaale. However, I claim here that there are two more important underlying causes, namely demographic change and nativism, which I examine in turn.

\section{A. Population Growth and Conflict}

Like most countries in Africa, Uganda has historically been under-populated, with traditional political structures more concerned about power over people than power over land (Herbst 2000). Yet by the early colonial period it was already apparent to the British that south-west Uganda, along with the neighbouring German colonies of Rwanda and Burundi, had high population densities and high population growth rates (Baker 1937). ${ }^{8}$ In 1945 the Protectorate government conducted a study in the area, which showed that the population surrounding greater Kabale town had

\footnotetext{
${ }^{6}$ The RCs were renamed Local Councils in Uganda's 1996 Constitution.

${ }^{7}$ Kibaale was the only district in Uganda to be mentioned by name in the Act.

${ }^{8}$ Part of the reason for overpopulation in Kigezi was due to immigration from Rwanda, especially during the 1927 famine (Ngologoza 1998: 76-77). This immigration - which was encouraged by Protectorate officials as it lowered local labour wages - and the colonial pressure to produce cash crops for export were, however, more responsible for the land degradation in the area than overpopulation per se (Ashley 2005: 6).
} 
grown by $60 \%$ in the previous twenty years, producing worries that soil degradation in the area could eventually lead to starvation.

As such, the local district government sponsored an annual Gombolola (subcounty) soil conservation competition in order to help increase crop efficiency. Similarly, many Bakiga became

acutely aware of the inherent worth and security of land, as reflected in the long history of land shortages in south-western Uganda where they originate. Such a history of land shortages encourages them to more aggressively seek land to cultivate in the KNP [Kibale National Park] area, than if land shortages were not a problem in their home area (Mulley and Unruh 2004: 204).

Thus, as a result of coming from a highly populated region, the Bakiga began to be known in Uganda for being hard-working and industrious. This ethnic stereotype made it easier for the government to launch a series of resettlement schemes for Bakiga to migrate to other parts of Uganda, with the hope that they would be viewed as economically beneficial to their new home regions. The first of these schemes was started in 1946, whereby residents of the overcrowded areas around Kabale were voluntarily moved to the two northern-most and least-populated counties in the district, Kinkizi and Ruzumbura (Protectorate of Uganda 1949: 74). However, the scheme was so popular that it attracted more applicants than places, and after 15,000 Bakiga moved north by the end of 1949, the Protectorate government decided to open up a new resettlement site for 'surplus Bakiga' in the north-west corner of Ankole kingdom (Protectorate of Uganda 1950: 104; Protectorate of Uganda 1951: 90). While thousands more Bakiga moved to Ankole, the Protectorate government was nonetheless worried that its efforts would not be effective in the long run, noting that 'it would appear that resettlement in itself except on a vast and continuing scale to areas outside the district will not be a complete solution to the problem' (Protectorate of Uganda 1954: 97). Indeed, already by 1955 the government recommended creating a new settlement site in the kingdom of Toro, which had welcomed over 42,000 people by 1960 (Ngologoza 1998: 99).

Thus, as with neighbouring Rwanda and Burundi, Kigezi had become so highly populated by this time that migration and resettlement were viable options for many local peasants. Yet it is wrong to assume that the Bakiga had only two options: 'either to migrate..., or starve in their over-populated districts' (Kulumba 2004: 27). Indeed, neither Edel (1957) nor Ngologoza (1998 [1967]) present any ethnographic evidence that the Bakiga were at any point under serious threat of wide-spread famine due to over-population, while Carswell (2003b) correctly rubbishes the idea that mild food shortages constituted a famine in Kigezi in 1943.

On the contrary, as seen by the large number of voluntary migrants who have continuously left the region since the 1920s to work elsewhere in Uganda (Carswell 2003a: 535), the Bakiga migrants quite obviously wanted to move to an area where they had more access to land. Indeed, the migrants' desire for more land belies the Protectorate administration's puzzlement that, upon moving to Ankole, a number of Bakiga had somehow acquired 'more land than was necessary' (Protectorate of Uganda 1951: 114). A similar rationale explains why so many Bakiga left for Kibaale, as their choice consisted of remaining on an average plot of less than three acres per taxpayer or moving to a guaranteed plot of ten acres (Carswell 2003a: 525). In other words, the Malthusian myth of overpopulation leading to starvation was just 
as untrue in Kigezi as it was in colonial Rwanda, many of whose 'surplus' residents emigrated to Uganda from the 1920s onwards. ${ }^{9}$

However spurious the fear of large-scale famine was, the high population density of Kigezi was indeed real. Yet the British efforts to encourage resettlement may have actually exacerbated matters: by providing Bakiga migrants with free transport, free food for six months, free housing and a two-year tax holiday (Ngologoza 1998: 90), the British thereby created 'a vacuum, which encouraged continued [population] growth' in Kigezi (Ashley 2005: 13). Nonetheless, with a precedence of government resettlement schemes already in place, the district governments of Kigezi and Bunyoro and the national government agreed upon the socalled Kagadi or Ruteete Resettlement Scheme in $1973,{ }^{10}$ whereby 100 square miles was set aside for a number of unemployed Bakiga tea workers from Toro in Buyaga county (Interview with District Chairman George Namyaka, Kibaale town, 9/8/05). Similarly, the aforementioned resettlement of Bakiga squatters from Kabaraole district in 1992 - whose population density today remains more than twice that of Kibaale - were resettled on 100 square miles in Bugangaizi county (Schelnberger 2005: 28). In both cases many settlers encouraged their relatives from Kigezi to migrate north in order to buy and settle land in Kibaale.

The result of this ongoing migration of Bakiga to Kibaale over the course of the 1990s meant that the population increased from 220,300 to 413,000 between the 1991 and 2002 censuses, an average annual population increase of 5.9\%. Despite the fact that Kibaale still remains beyond any major transportation routes - to reach the district one cannot take a direct taxi or bus from Kampala but must change in Mubende town - the 2002 census records a population density of 98 people per square kilometre in the district, higher than in nearby Kyenjojo (96), Hoima (95), Luwero (88), Sembabule (79), Kiboga (59), Masindi (54) and Nakasongola (41) districts.

Thus, instead of merely allowing Bakiga to emigrate freely to other parts of Uganda as they had already done for decades, both the British and the Museveni resettlement schemes created artificial non-market incentives for migration. While the district is still far more sparsely populated than Kisoro (324) and Kabale (281) districts in Kigezi, ${ }^{11}$ the resulting immigration has led to 'problems with land galore' in Kibaale (Interview with Resident District Commissioner Hajji Ali Mutawe, Kibaale town, 8/8/05). The resettlement schemes were inevitably blamed for favouring Bakiga at the expense of the 'indigenous' Banyoro or Batoro who had not received any free land from the government, and the controversy over the schemes has led to several violent clashes between the Bakiga settlers and the Banyoro-controlled District Land Board in its attempt to distribute public land to Banyoro (New Vision 2003b).

Of course, this was not the only problem with the Ugandan government's demographic policies. There never would have been a need to resettle Bakiga in the first place if Uganda's high fertility had been tackled much earlier through more effective education and contraceptive policies. Before Museveni implemented his

\footnotetext{
${ }^{9}$ See for instance Blanc (1984)'s ill-placed worry about food shortage in Rwanda by the year 2000 due to overpopulation.

10 After President Milton Obote abolished all kingdoms in Uganda in 1967, all of the Bunyoro kingdom's former territory was incorporated into Bunyoro district. In 1974 this district was subsequently divided into North and South Bunyoro; in 1980 the latter was renamed Hoima District, comprising the current districts of Hoima and Kibaale.

${ }^{11}$ For point of reference, at 324 people per square kilometre Kisoro district is more densely populated than Rwanda (322 people per square kilometre), the most densely populated country in Africa.
} 
1995 Population policy, only married women could obtain contraceptives, and then only with permission of their husband (Blacker et al. 2005: 368); yet even after the policy was implemented only $13 \%$ of women wishing to stop having children were using contraceptives in one district in central Uganda (Lutalo et al. 2000: 226). As a result the 2002 census showed Uganda's fertility rate at 7.0, or basically the same as the 7.1 rate measured in the 1969 census.

\section{B. Ethnicity and Conflict}

Yet demographic change by itself cannot explain the Kibaale conflict. Indeed, the aforementioned resettlement schemes were initially welcomed by both parties. The Bakiga were happy to receive land, while the Banyoro were happy to allow the Bakiga to settle in between the Banyoro and the unpopulated bush or forest areas, thereby protecting Banyoro farms from unwanted animals (Interview with John Baptist Sentoogo Amooti, Kibaale town, 9/8/05). Partially due to the large numbers killed in the war between the British and the Banyoro in the late $19^{\text {th }}$-century and partially due to being so far removed from any major transportation or commercial hubs, Kibaale had remained under-populated and under-developed throughout the colonial period (Green 2006b), and was thus ideally suited for new settlers from other parts of the country.

The key problem with the scheme, however, was its assumption that the two groups would be able not only to coexist but prosper together. Indeed, ethnic conflict resulting from the internal migration of Bakiga has by no means been limited to Kibaale. The aforementioned scheme to resettle Bakiga in Ankole in the 1950s drew the ire of local -kole leaders, who at one point threatened to block any further immigration from the south-west (Bisiika 2006), while Mulley and Unruh (2004: 202) note current rising tensions between Banyoro and Bakiga living around Kibale National Park in Kabarole district. In Hoima district a number of Bakiga migrants were evicted from their land in 2002; some 160 of these evictees later camped outside the Uganda Parliament building in protest of their treatment before being resettled temporarily at a sports stadium in Kampala. When the government then attempted to permanently resettle these Banyoro in Kiboga district (neighbouring Kibaale to the east), violent protests in Kiboga led to the decision to relocate the Bakiga to an undisclosed location in Mubende district (New Vision 2003a).

On the one hand this wide-spread dislike of Bakiga settlers seems to make little sense, as not only are the Bakiga ethnically similar to the Banyoro and the Batoro - the three groups speak what are often considered similar and mutually intelligible dialects of the western Intralacustrine Bantu language (Prah 2004) - but there has been no history of conflict between the Bakiga and the Batoro or the Banyoro as between the Baganda and the Banyoro. On the other hand, the xenophobia towards Bakiga makes sense if we recall that, in most of Africa, local citizenship and rights are still very much tied up with ethnic identity (Boone 2003: 349). In this sense it is important to recall that the conflict began after the 2002 election for LCV Chairman, the most important political office in the district and a source of ethnic patronage at the local level.

This analysis does not, however, suggest that ethnic diversity per se has played any role in the Kibaale conflict. On the contrary, Kibaale is not itself ethnically diverse in comparison with Kampala or surrounding districts in central Uganda, some of which are self-described as the 'United Nations of Uganda' due to 
their extreme ethnic diversity. ${ }^{12}$ Rather, ethnicity nonetheless plays a major role in the conflict in Kibaale in the form of nativism. What is indeed striking in Kibaale is the way the local Banyoro repeatedly refer to both the Bakiga migrants to Kibaale and the absentee Baganda landlords who own land in the district as non-natives, despite the fact that members of all three groups are Ugandan citizens. For instance, one local councillor claimed that 'the majority of the land in Kibaale should be for Banyoro because we have never moved anywhere - we are from here. The Bakiga have land in their own area' (Interview with John Baptist Sentoogo Amooti, Kibaale town, 9/8/05). Similarly, Kasirivu Atwooki, the new Minister of State for Lands and a native Munyoro from Kibaale like his predecessor, claimed that both the Baganda absentee landlords and the Bakiga settlers were 'foreigners' (Wadri 2006). Most striking in this sense is the claim of the MBC chairman, Katta Musoke, who stated that 'Uganda does not exist. What matters is Bunyoro, Kigezi, Buganda, not Uganda' (Interview with Katta Musoke, Kibaale town, 9/8/05).

While Musoke is undoubtedly an extremist, his analysis of the failed state of Ugandan nation-building is nonetheless consistent with other those of other Ugandans. ${ }^{13}$ Despite the optimism of African nationalists like the late President of Guinea Sékou Touré, who claimed in 1959 that 'in three of four years, no one will remember the tribal, ethnic or religious rivalries which, in the recent past, caused so much damage to our country and its population' (quoted in Young 1996: 42), there is general agreement that attempts at nation-building in post-colonial Africa have largely failed to overcome ethnic and other communal divisions (Berman et al. 2004; Young 2001). Indeed, as the national newspaper The New Vision (2003b) noted in an editorial, 'the problem in Kibaale represents the challenge of nationhood in many African countries where nationality and citizenship is still influenced by nativism. It is an irony that a Ugandan who leaves his or her native district becomes a foreigner in a neighbouring district. ${ }^{14}$

In other words, the conflict in Kibaale is not at heart a result of two ethnic groups competing for resources but rather a consequence of the way that the failures of Ugandan nation-building have left local claims of indigeneity as a means to exclude fellow citizens from access to resources. Indeed, in this sense Mamdani (1996: 208) was premature and ultimately wrong to praise President Museveni's introduction of the Resistance Council (RC) system of local government as one of 'enormous significance,' inasmuch as Museveni 'redefined the basis of rights from descent to residence.' As the Kibaale example sadly makes clear, the shift to a residence-based system of rights has merely meant that ethnic conflicts have been reframed rather than removed: whereas in the past rural political contestation took place between groups distinguished by tribe or ethnicity, it now takes place between groups claiming indigeneity over local political jurisdictions. Indeed, as most ethnic groups continue to be defined along territorial lines in Uganda - and elsewhere in Africa - the RC system may have helped to devolve ethnic conflict from the regional to the local level, but it has neither changed the names of the groups in conflict with

\footnotetext{
${ }^{12}$ In this sense the Kibaale conflict would seem to support the aforementioned inverse-U relationship between ethnicity and conflict, whereby ethnicity is most dangerous when only two ethnic groups are present.

${ }^{13}$ Cf. Dominic (2003), who writes that 'we [Ugandans] have clutched onto our ethnic identities to the detriment of developing our national identity.'

${ }^{14}$ Incidentally, the same scheme of using migrant Bakiga as buffers against crop damage in Kibaale and Kabarole districts has also been employed towards Congolese immigrants in Masindi district (Naughton-Treves 1997: 37).
} 
each other nor has it done anything to reduce the amount of ethnic conflict or advance nation building. In Uganda Mamdani's ethnic subjects have indeed become citizens, but as local-level conflict has continued to be based along tribal/ethnic lines, Museveni’s reforms are considerably less impressive than Mamdani suggests.

\section{Conclusion}

In hindsight the conflict in Kibaale is easily explicable. First, poor population policies by both British colonial and independent Ugandan governments have led to a large and often sudden influxes of Bakiga into Kibaale. Second, the failures of Ugandan nation-building meant that the Bakiga migrants were not accepted as sharing the same rights over local resources as the 'indigenous' Banyoro, leading to the outbreak of conflict when a Mukiga was elected as District Chairman. The two factors could thus be said to be necessary but independently not sufficient in explaining Kibaale's recent troubles.

Neither factor is, unfortunately, unique to either Kibaale or Uganda. Nativism, here examined as local conflict over resources along lines of indigeneity, is prominent throughout Africa. Vlassenroot and Raeymaekers (2004), for instance, discuss the current conflict in Ituri, across the border from Uganda in the Democratic Republic of Congo, as a struggle over land and local resources. As in Kibaale, this conflict also took on a division based on indigeneity, this time between the Hema and Gegere 'originaires' and the Lendu 'non-originaires' (Vlassenroot and Raeymaekers (2004: 397). ${ }^{15}$ Similarly, in Botswana many San have claimed to be more indigenous than the Bakgalagadi ethnic group in their attempt to control access to land in the Central Kalahari Game Reserve, claiming to be 'the first people' in the area (Hitchcock 2002). Finally, in Nigeria local and state-level politics revolves around the status of 'indigenes' and 'non-indigenes,' or 'internal foreigners' in Kraxberger (2005)'s terminology.

Mamdani (1996; 2001) has also given prominence to the concept of indigeneity and nativism in contemporary Africa as a prominent legacy of late colonialism. His analysis has been focussed on the central state level - for instance in his analysis of Hutu/Tutsi relations in Rwanda - whereby indigeneity defines national citizenship. In the case of Kibaale and other examples mentioned above, however, it is clear that it is local citizenship which has been infused with questions of indigeneity. While Mamdani (1996; 2001) would seem to suggest that nativism and xenophobia are insipient signs of a budding national identity, whereby indigeneity is tied up with belonging to the Ugandan or Rwandan polity, here the evidence suggests that even within these polities indigeneity plays a prominent role in local politics. In this sense nativism is much more prominent and pernicious than Mamdani's analysis would lead us to believe, and one that, as already mentioned, is unlikely to be resolved by redefining rights along residence rather than descent lines.

The importance of indigeneity and nativism to local conflict in Africa does not, however, absolve scholars from analyses of demographic change. It is indeed striking how, as the twentieth anniversary of Yoweri Museveni's rule in Uganda came and went, outside observers and scholars took the opportunity to reflect on his accomplishments and failures without once mentioning Uganda's extraordinary population growth rate (cf. Barkan 2005, Carson 2005, Hickey 2005, Robinson 2006).

\footnotetext{
${ }^{15}$ As in Kibaale and the Rwandan genocide of 1994, the Ituri conflict is also notable for the spread of hate speech through the radio, an invaluable tool for propaganda and information in rural Africa.
} 
Yet Museveni has consistently remained a vociferous supporter of population growth, welcoming the news in 2005 that Uganda's population had doubled since he took over as President in 1986. ${ }^{16}$ As demonstrated here, population growth and demographic policies can play a significant role in local-level conflict, one that scholars cannot afford to neglect.

In the end it is clear that local-level conflict is both a major problem in countries such as Uganda and is unlikely to disappear any time soon. Indeed, violence in Kibaale flared up again in early 2006 after two Bakiga politicians were elected MPs in the latest Parliamentary elections, leading to more inter-ethnic violence, arson and threats of expulsion. As indicated here, the only two potential solutions to such clashes are long-term, namely the institution of a demographic policy which aims to drastically reduce Uganda's high population growth rate, and greater efforts at nation-building. Of the two, while the former is certainly easier to accomplish, the latter is perhaps more important in the long run. Only when nativism and the politics of indigeneity are removed from the local arena will ethnic conflict in places like Kibaale diminish.

\footnotetext{
${ }^{16}$ Museveni also noted that, 'among the Banyankore [Museveni’s ethnic group], when you praise somebody you say "I wish you many children.” I am happy that I have implemented the Banyankore philosophy.' New Vision, 25 March 2005.
} 


\section{Bibliography}

Alston, Lee J., Gary D. Libecap and Bernarno Mueller. 2001. 'A Model of Rural Conflict: Violence and Land Reform Policy in Brazil.' Environment and Development Economics 4, 2: 135-160.

Ashley, Rebecca. 2005. 'Colonial Problems, Contemporary Problems: Digging to the Root of Environmental Degradation in Kabale, Uganda.' Agroforestry in Landscape Mosaics Working Paper. World Agroforestry Centre, Tropical Resources Institute of Yale University and University of Georgia.

Associated Press. 2005. 'Free-Staters Seek Offices.' [Manchester, NH] Union Leader, September 23.

Baker, SJK. 1937. 'The Distribution of Native Population over East Africa.' Africa: Journal of the International African Institute 10, 1: 37-54.

Barkan, Joel. 2005. 'An African “Success” Past its Prime.' Presentation at Woodrow Wilson International Center for Scholars Africa Program Conference on Challenges and Change in Uganda, Washington, DC.

Barron, Patrick, Kai Kaiser and Menno Pradhan. 2004. 'Local Conflict in Indonesia: Measuring Incidence and Identifying Patterns.' World Bank Policy Research Working Paper No. 3384, Washington D.C.

Berman, Bruce, Dickson Eyoh and Will Kymlicka. 2004. 'Ethnicity and the Politics of Democratic Nation-Building in Africa.’ Ethnicity and Democracy in Africa. Ed. Bruce Berman, Dickson Eyoh and Will Kymlicka. Oxford: James Currey.

Bisiika, Asuman. 2006. 'Kibaale Clashes: How it all Started.’ The Monitor, March 19.

Blacker, John, Collins Opiyo, Momodou Jasseh, Andy Sloggett and John SsekamatteSsebuliba. 2005. 'Fertility in Kenya and Uganda: A Comparative Study of Trends and Determinants.’ Population Studies 59, 3: 355-373.

Blanc, Paul. 1984. 'Environmental Health and Development in a Developing Country: Rwanda, A Case Study.' Journal of Public Health Policy 5, 2: 271-288.

Boone, Catherine. 2003. Political Topographies of the African State: Territorial Authority and Institutional Choice. Cambridge: Cambridge University Press.

Carson, Johnnie. 2005. 'A Legacy in Danger.' Presentation at Woodrow Wilson International Center for Scholars Africa Program Conference on Challenges and Change in Uganda, Washington, DC.

Carswell, Grace. 2003a. 'Food Crops as Cash Crops: The Case of Colonial Kigezi, Uganda.' Journal of Agrarian Change 3, 4: 521-551.

_ 2003b. 'Soil Conservation Policies in Colonial Kigezi, Uganda.' Social History and African Environments. Ed. William Beinert and JoAnn McGregor. Oxford: James Currey.

Collier, Paula and Anke Hoeffler. 1998. 'On Economic Causes of Civil War.' Oxford Economic Papers 50, 4: 563-573.

_. 2000. 'On the Incidence of Civil War in Africa.' Mimeo, World Bank.

De Soysa, Indra. 2002. 'Paradise is a Bazaar? Greed, Creed and Governance in Civil War, 1989-1999.' Journal of Peace Research 39, 4: 395-416. 
DeVotta, Neil. 2002. 'Demography and Communalism in India.' Journal of International Affairs 56, 1: 53-70.

Dominic, Dipio. 2003. 'A Nation in Dire Need of Prayer.' The Monitor, May 10.

Edel, Mary Mandelbaum. 1957. The Chiga of Western Uganda. New York: Oxford University Press.

Fearon, James. 2003. 'Ethnic and Cultural Diversity by Country.' Journal of Economic Growth 8, 2: 195-222.

Fearon, James and David Laitin. 1996. 'Explaining Interethnic Cooperation.' American Political Science Review 90, 4: 715-735.

Green, Elliott. 2006a. 'Ethnicity and the Politics of Land Tenure Reform in Central Uganda.' Commonwealth and Comparative Politics 44, 3: forthcoming. . 2006b. 'Understanding the Limits to Ethnic Change: Evidence from Uganda's 'Lost Counties.' Mimeo, Development Studies Institute, LSE.

Herbst, Jeffrey. 2000. States and Power in Africa: Comparative Lessons in Authority and Control. Princeton, NJ: Princeton University Press.

Hickey, Sam. 2005. 'The Politics of Staying Poor: Exploring the Political Space for Poverty Reduction in Uganda.' World Development 33, 6: 995-1009.

Hitchcock, Robert K. 2002. “"We are the First People”: Land, Natural Resources and Identity in the Central Kalahari, Botswana.' Journal of Southern African Studies 28, 4: 797-824.

Homer-Dixon, Thomas F. 1999. Environment, Scarcity and Violence. Princeton, NJ: Princeton University Press.

Kraxberger, Brennan. 2005. 'Strangers, Indigenes and Settlers: Contested Geographies of Citizenship in Nigeria.' Space and Polity 9, 1: 9-27.

Krebs, Ronald R. and Jack Levy. 2001. 'Demographic Change and the Sources of International Conflict.' Moving Targets: Demography and Security. Ed. Myron Weiner and Sharon S. Russell. New York: Berghahn.

Kulumba, Mohammed. 2004. 'Ethnocentrism and Movement Politics in Uganda: An Analysis of the Ethnic Conflict During the 2002 District Council Elections in Kibaale District.' Post-Colonial Studies in Africa. Ed. Akim Okuni and Richard Ssewakiryanga. Kampala: Centre for Basic Research.

Lutalo, Thomas, Medi Kidugavu, Maria J. Wawer, David Serwadda, Laurie Schwab Zabin and Ronald H. Gray. 2000. 'Trends and Determinants of Contraceptive Use in Rakai District, Uganda, 1995-1998.' Studies in Family Planning 31, 3: 217-227.

Mamdani, Mahmood. 1996. Citizen and Subject: Contemporary Africa and the Legacy of Late Colonialism. Princeton, NJ: Princeton University Press.

. 2001. When Victims Become Killers: Colonialism, Nativism and the Genocide in Rwanda. Princeton, NJ: Princeton University Press.

Maxwell, John W. and Rafael Reuveny. 2000. 'Resource Scarcity and Conflict in Developing Countries.’ Journal of Peace Research 37, 3: 301-322. 
Mulley, Brad G. and Jon D. Unruh. 2004. 'The Role of Off-Farm Employment in Tropical Forest Conservation: Labour, Migration and Smallholder Attitudes toward Land in Western Uganda.' Journal of Environmental Management 71, 3: 193-205.

Nagourney, Adam. 2000. 'Pitfalls for Hillary Clinton: Carpetbagger Issue has Echoes of '64, but Differences Could Prove Crucial.' New York Times, September 10.

Naughton-Treves, Lisa. 1997. 'Farming the Forest Edge: Vulnerable Places and People around Kibale National Park, Uganda.’ Geographical Review 87, 1: 2746.

New Vision. 2003a. 'Bakiga Families Settled.’ New Vision, November 3.

. 2003b. 'Kibaale: A Political Conflict that Needs a Moral Solution.' New Vision, June 11.

Ngologoza, Paul. 1998 [1967]. Kigezi and its People. Kampala: Fountain.

Prah, Kwesi Kwaa. 2004. 'African Wars and Ethnic Conflicts - Rebuilding Failed States.' Africa Regional Background Paper, Human Development Report 2004. UNDP.

Reilly, Benjamin. 2000. 'Democracy, Ethnic Fragmentation and Internal Conflict: Confused Theories, Faulty Data and the "Crucial Case” of Papua New Guinea.' International Security 25, 3: 162-185.

Robinson, Mark. 2006. 'Uganda.’ IDS Bulletin 37, 2: 14-26.

Schelnberger, Anna Katharina. 2005. 'Decentralization as a Means of Conflict Management: A Case Study of Kibaale District, Uganda.' Working Paper No. 181, Institute of Development Research and Development Policy, Ruhr University of Bochum.

Tir, Jaroslav and Paul Diehl. 1998. 'Demographic Pressure and Interstate Conflict: Linking Population Growth and Density to Militarized Disputes and Wars, 1930-1989.' Journal of Peace Research 35, 3: 319-339.

Uganda, Protectorate of. 1949. Annual Report on the Western Province (Including Northern Province) for the Period 1939-1946. Entebbe: Government Printer.

. 1950. Annual Report on the Western Province for the Year ended $31^{\text {st }}$ December, 1949. Entebbe: Government Printer.

1951. Annual Report on the Western Province for the Year ended $31^{\text {st }}$ December, 1950. Entebbe: Government Printer.

. 1954. Annual Report on the Western Province for the Year ended $31^{\text {st }}$ December, 1953. Entebbe: Government Printer.

Uganda, Republic of. 1989. Demographic and Health Survey 1988/1989. Ministry of Health, Entebbe.

UNDP. 2005. Human Development Report. New York: United Nations.

Urdal, Henrik. 2005. 'People vs. Malthus: Population Pressure, Environmental Degradation and Armed Conflict Revisited.' Journal of Peace Research 42, 4: 417-434. 
Varshney, Ashutosh. 2002. Ethnic Conflict and Civic Life: Hindus and Muslims in India. New Haven, CT: Yale University Press.

Vlassenroot, Koen and Timothy Raeymaekers. 2004. 'The Politics of Rebellion and Intervention in Ituri: The Emergence of a New Political Complex?' African Affairs 103, 412: 385-412.

Wadri, Peter. 2006. 'Kasirivu vows to End Kibaale Land Wrangles.' The Monitor, June 16.

Young, Crawford. 1996. 'Evolving Modes of Consciousness and Ideology: Nationalism and Ethnicity.' Political Development and the New Realism in SubSaharan Africa. Ed. David E. Apter and Carl G. Rosberg. London: University Press of Virginia.

_. 2001. 'Nationalism and Ethnic Conflict in Africa.' Understanding Nationalism. Ed. Montserrat Guibernau and John Hutchinson. Cambridge: Polity. 